\title{
Artificial mixing to control cyanobacterial blooms: a review
}

\author{
Petra M. Visser • Bas W. Ibelings • \\ Myriam Bormans $\cdot$ Jef Huisman
}

Received: 10 February 2015/Accepted: 29 July 2015/Published online: 19 August 2015

(C) The Author(s) 2015. This article is published with open access at Springerlink.com

\begin{abstract}
Artificial mixing has been used as a measure to prevent the growth of cyanobacteria in eutrophic lakes and reservoirs for many years. In this paper, we give an overview of studies that report on the results of this remedy. Generally, artificial mixing causes an increase in the oxygen content of the water, an increase in the temperature in the deep layers but a decrease in the upper layers, while the standing crop of phytoplankton (i.e. the chlorophyll content per $\mathrm{m}^{2}$ ) often increases partly due to an increase in nutrients entrained from the hypolimnion or resuspended from the sediments. A change in composition from cyanobacterial dominance to green algae and diatoms
\end{abstract}

Guest editors: Petra M. Visser, Bas W. Ibelings, Jutta Fastner \& Myriam Bormans/Cyanobacterial blooms. Ecology, prevention, mitigation and control.

P. M. Visser $(\bowtie) \cdot$ J. Huisman

Department of Aquatic Microbiology, Institute for Biodiversity and Ecosystem Dynamics, University of Amsterdam, PO Box 94248, 1090 GE Amsterdam, The Netherlands

e-mail: p.m.visser@uva.nl

B. W. Ibelings

Institute F.-A. Forel, Institute for Environmental Sciences, University of Geneva, 10 Route de Suisse, 1290 Versoix, Switzerland

M. Bormans

UMR CNRS 6553 - ECOBIO, Université de Rennes 1, Bât 14B, Campus de Beaulieu, 35042 Rennes Cedex, France can be observed if the imposed mixing is strong enough to keep the cyanobacteria entrained in the turbulent flow, the mixing is deep enough to limit light availability and the mixing devices are well distributed horizontally over the lake. Both models and experimental studies show that if phytoplankton is entrained in the turbulent flow and redistributed vertically over the entire depth, green algae and diatoms win the competition over (colonial) cyanobacteria due to a higher growth rate and reduced sedimentation losses. The advantage of buoyant cyanobacteria to float up to the illuminated upper layers is eradicated in a wellmixed system.

Keywords Artificial mixing - Destratification - Lake management $\cdot$ Blue-green algae $\cdot$ Cyanobacteria

\section{Introduction}

Many eutrophic systems worldwide experience cyanobacterial blooms that have a suite of negative impacts on ecosystem functioning including a loss of aquatic biodiversity, low transparency and the occurrence of surface blooms or scums. Cyanobacteria also can negatively affect domestic and wild animals as well as human health since they have the potential to produce toxins (see overview Merel et al. 2013), and numerous animal and human intoxications by cyanobacterial toxins have been reported (e.g. Kuiper-Goodman et al. 1999; Cox et al. 2003; Griffiths 
and Saker 2003; Hilborn et al. 2007). Hence, cyanobacterial dominance in water systems can have serious economical and societal consequences as it impedes important ecosystem services of inland waters including recreational use, aquaculture, water usage for irrigation and drinking water usage (Paerl and Huisman 2009; Ibelings et al. 2014).

Moreover, the presence of cyanobacteria may lead to other problems if the water is used for drinking water preparation. Cyanobacteria may produce offflavour compounds such as geosmins (Jähnichen et al. 2011). Furthermore, high algal or cyanobacterial biomass may lead to an anaerobic hypolimnetic layer in deep lakes where reduced substances such as $\mathrm{Fe}^{2+}$, $\mathrm{Mn}^{2+}$ and $\mathrm{H}_{2} \mathrm{~S}$ may accumulate leading to deterioration of the lake as a source of drinking water. The anaerobic conditions in the sediment are the result of microbial decomposition and often cause the release of large quantities of phosphate (e.g. Lehman 2011), because the phosphate-iron binding is not maintained under anaerobic conditions. Hypolimnetic oxygenation techniques are in use to prevent the production of reduced substances in the sediment while the stratification is maintained. This oxygenation creates more oxidized conditions in the water above the sediment and thus helps to prevent phosphate release in a lake (e.g. Taggart and McQueen 1981; Ashley 1983) unless excessive organic matter is present (Gächter and Wehrli 1998). The decrease in internal $P$ loading in a lake of reservoir by hypolimnetic aeration can play an important role in the restoration of a lake or reservoir (Bormans et al. 2015).

Artificial mixing or circulation has the aim to eliminate the stratification in the system and affect the growth of phytoplankton by the associated changing physical conditions. More specifically, the dynamics of the phytoplankton community in hypertrophic and eutrophic systems are often strongly driven by competition for light, which availability is directly impacted by the physical structure of the water column and the distribution of the cells (Huisman et al. 2004). Manipulation of the physical structure of a lake by artificial mixing can lead to a change in the phytoplankton composition and/or biomass. Artificial mixing often aims to reduce algal and/or cyanobacterial growth for drinking water or recreational purposes, to avoid fish kills or even to stimulate fish stock in the water. Originally, it was developed to obtain a higher productivity of trout in Michigan lakes (Hooper et al. 1953). Yet, since that study it has mostly been employed to improve water quality in ponds, lakes and reservoirs (Barbiero et al. 1996; Visser et al. 1996b; Heo and Kim 2004). Furthermore, artificial mixing has been applied with the specific aim to reduce the growth conditions for cyanobacteria and prevent scum-forming cyanobacteria.

On the basis of artificial mixing experiments in enclosures, Reynolds et al. (1983) distinguished four groups of phytoplankton that each responded differently to deep mixing: (1) phytoplankton favoured by mixing (Asterionella, Fragilaria, Staurastrum, Oscillatoria), (2) phytoplankton favoured by stability and/ or reduced optical depth but whose increase stimulates cropping by zooplankton, and in turn enhances loss rates by grazing (Cryptomonas, Rhodomonas, Ankyra), (3) phytoplankton whose growth is merely arrested by episodes of deep-column mixing ( $A n$ abaena, Ceratium, Volvox, Microcystis) and (4) phytoplankton whose growth is abruptly reversed by episodes of deep-column mixing (Sphaerocystis, Eudorina). From these experiments, it became clear that deep mixing hampers the growth of the cyanobacteria Microcystis and Anabaena, while diatoms (Asterionella, Fragilaria, Staurastrum) are favoured by deep mixing. It also shows that the response is not the same for all cyanobacteria, as mixing favours Oscillatoria agardhii (now called Planktothrix agardhii).

In this paper, we present an overview of studies in which artificial mixing was applied, successfully or not, to control cyanobacteria in lakes and reservoirs. First, the working mechanism of the prevention of cyanobacterial growth by artificial mixing is explained and further elucidated by the introduction of a 1D model. Next, buoyancy regulation by cyanobacteria is explained, and we review some of the state-of-the-art models of vertical migration and mixing. We subsequently describe the different mixing devices and the effects of artificial mixing in lakes and reservoirs that have been reported so far. Finally, we strive to define the conditions required for a successful application of artificial mixing to combat cyanobacteria in lakes.

\section{The working mechanism}

To understand the effect of artificial mixing on the growth of cyanobacteria, some physiological characteristics of cyanobacteria need to be elucidated (Carey 
et al. 2012; Mantzouki et al. 2015). An important feature explaining the success of many bloom-forming cyanobacteria is buoyancy. Buoyancy is provided by gas vesicles, hollow proteinaceous structures in the cells (Walsby 1994). Being buoyant allows cyanobacteria to remain in the upper illuminated water layer of a stratified lake and increase their total daily light dose (Ibelings et al. 1991; Köhler 1992), while other negatively buoyant phytoplankton sinks out of these layers. Artificial mixing leads to an increased mixing depth, which affects the competition between cyanobacteria and algae in two ways: (1) negatively buoyant algae have reduced sedimentation losses, and hence, their net growth rate tends to increase and (2) buoyant cyanobacteria entrained in the deep, artificially induced turbulence experience a lower light dose and stronger light fluctuations, and hence, their net growth rate tends to decrease.

Sedimentation is a significant loss process for diatoms and non-motile green algae (Sommer 1988; Ptacnik et al. 2003). Both the depth of the mixed layer and the intrinsic settling velocity of the algae determine the extent of sedimentation losses of the negatively buoyant species in a lake (Visser et al. 1996a; Jäger et al. 2008). In a stratified lake with only a shallow mixed layer, sedimentation losses of nonbuoyant algae are generally high. However, the sedimentation losses decrease with increasing mixing depth. While entrained in the mixed layer, the average light dose experienced by the phytoplankton decreases with deepening of the mixing. Furthermore, the ratio of the mixing depth to the euphotic depth $\left(Z_{\mathrm{m}} / Z_{\mathrm{eu}}\right)$ increases when the mixing deepens. An increase in this ratio implies exposure to larger fluctuations in photon irradiance. Eukaryotic algae such as green algae and diatoms seem better adapted to these fluctuations (Flameling and Kromkamp 1997; Nicklisch 1998; Litchman 2000), while many cyanobacteria seem more sensitive. A study by Ibelings et al. (1994) in laboratory cultures showed that the cyanobacterium Microcystis was more sensitive to changes in photon irradiance than the green alga Scenedesmus. In a field experiment, Mitrovic et al. (2003) showed a decrease in Microcystis (but also of Scenedesmus) under fluctuating light, while the diatom Skeletonema was found to increase compared to static light conditions.

In conclusion, of the various effects that artificial mixing has on the environmental conditions in a lake

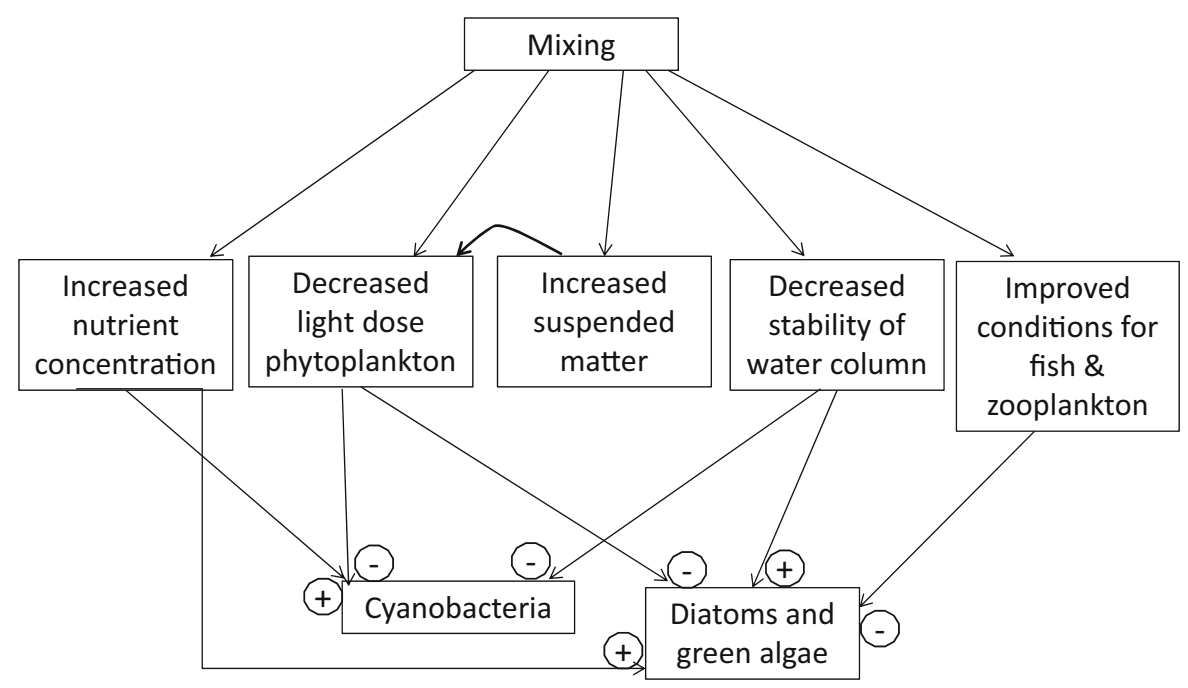

Fig. 1 Diagram showing the general effects of artificial mixing on algae and cyanobacteria (after Shapiro 1979). Mixing can lead to a higher nutrient concentration in deep stratified lakes due to nutrient-rich hypolimnetic waters. Higher nutrient concentrations can alleviate nutrient limitation of cyanobacteria and algae and increase the growth rate. Deep mixing will reduce the light dose as experienced by phytoplankton and will increase the amount of suspended matter in the water column. Reduced light exposure will lead to decreased growth of cyanobacteria and algae. Decreased stability of the water column will benefit diatoms and green algae, but will be disadvantageous for buoyant cyanobacteria. Due to the increased oxygen concentrations that are generally the result of mixing, the conditions for fish and zooplankton may improve. More zooplankton generates higher grazing of algae and will decrease the net growth rate of diatoms and algae 
(Fig. 1), it is mainly the decreased stability of the water column, which causes a shift from cyanobacteria to green algae and diatoms.

\section{Theory}

The impact of artificial mixing on the competitive balance between buoyant cyanobacteria and sinking phytoplankton, as outlined above, can be further explored by a simple 1D model. The model considers a vertical water column with several phytoplankton species. We assume a highly eutrophic system in which nutrients are in ample supply, and hence, the species mainly interact through mutual shading (i.e. competition for light). Let $N_{i}(z, t)$ denote the concentration of phytoplankton species $i$ at depth $z$ and time $t$. The population dynamics of a number of $n$ phytoplankton species depends on the growth rates and vertical velocities of the different species and also on turbulent mixing of the water column and the underwater light field. This can be described by the following set of partial differential equations (Klausmeier and Litchman 2001; Huisman et al. 2004):

$$
\begin{aligned}
\frac{\partial N_{i}}{\partial t} & =\mu_{i}(I(z, t)) N_{i}+v_{i}+\frac{\partial N_{i}}{\partial z}+D \frac{\partial^{2} N_{i}}{\partial z^{2}} \\
i & =1, \ldots, n
\end{aligned}
$$

Here, $\mu_{i}(I(z, t))$ is the net-specific growth rate of species $i$ as function of the local light intensity $I$ at depth $z$ and time $t, v_{i}$ is the vertical velocity of species $i$ (with $v_{i}<0$ for sinking species and $v_{i}>0$ for buoyant species), and $D$ is known as the turbulent diffusion coefficient or vertical eddy diffusivity. For notational convenience, we assume that the net-specific growth rate also includes phytoplankton losses due to, for example, natural mortality, viral lysis and zooplankton grazing. Light intensity decreases exponentially with depth according to Lambert-Beer's law, in which the light attenuation coefficient is a function of the background turbidity of the water column and the concentrations of the different phytoplankton species (Huisman et al. 2004). For the purpose of illustration, we have here assumed that the turbulent diffusion coefficient $D$ is constant over depth, but it is relatively straightforward to extend the model with depthdependent variation of $D$ (Huisman and Sommeijer 2002; Jöhnk et al. 2008). We assume zero-flux boundary conditions.

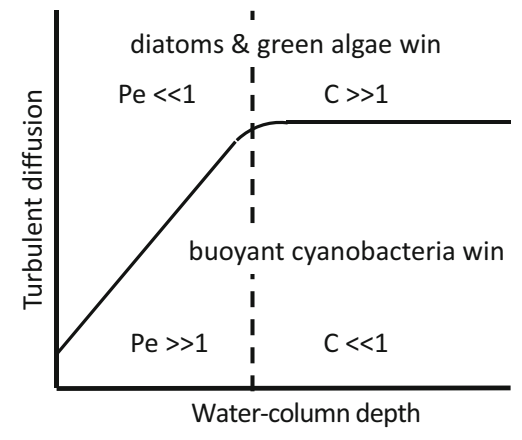

Fig. 2 Schematic overview of the dependency of the outcome of competition for light between buoyant cyanobacteria and the diatoms and green algae on the water-column depth and the turbulent diffusivity. Buoyant cyanobacteria will win if the Péclet number $(\mathrm{Pe})$ is much larger than 1 in shallow waters and the competition number $(C)$ is much smaller than 1 in deep waters. Conversely, diatoms and green algae will displace the buoyant cyanobacteria when these relationships are reversed. Adapted from Huisman et al. (2004)

The model predictions are shown in Fig. 2, for different combinations of the total water-column depth $z_{M}$ and the turbulent diffusion coefficient $D$. Buoyant cyanobacteria such as Microcystis tend to have a relatively low growth rate in comparison with most other phytoplankton species. The model predicts that the higher growth rates of green algae and diatoms compared to Microcystis lead to competitive exclusion of Microcystis in well-mixed environments. This prediction is supported by laboratory competition experiments (Huisman et al. 1999). In weakly mixed waters, Microcystis escapes the mixing and floats upwards, whereas diatoms and green algae are also not entrained but sink downwards, out of the surface layer. Hence, the model predicts that Microcystis displaces the diatoms and green algae in weakly mixed waters.

The different regions in Fig. 2 can be approximated by a few dimensionless numbers that capture the time scales of the relevant processes (Huisman et al. 2004). In relatively shallow waters $\left(z_{M}<30 \mathrm{~m}\right)$, the outcome of competition depends on the time scale of turbulent mixing $\left(\tau_{\text {mix }}\right)$ and the time scale of the vertical velocity obtained by flotation or sinking $\left(\tau_{\mathrm{vv}}\right)$ :

$\tau_{\text {mix }}=\frac{z_{M}^{2}}{D}$ and $\tau_{\mathrm{vv}}=\frac{z_{M}}{v_{i}}$

The time scale of turbulent mixing indicates the time required for a phytoplankter to travel through a watercolumn depth $z_{M}$ by means of turbulent mixing. The 
time scale of vertical velocity indicates the time required for a phytoplankter to travel through the water column by means of its sinking or flotation rate.

The dimensionless Péclet number, $P e$, is defined as the ratio of these two time scales (e.g. Condie 1999; O'Brien et al. 2003):

$P e_{i}=\frac{\tau_{\mathrm{mix}}}{\tau_{\mathrm{vv}}}=\frac{v_{i} z_{M}}{D}$

If the vertical velocity is much faster than the rate of turbulent mixing, the Péclet number is large. And if turbulent mixing dominates over sinking or flotation, the Péclet number is small. In our application, the diagonal boundary line between dominance of Microcystis and dominance of the diatoms and green algae in Fig. 2 can be described by the Péclet number. That is, the winner of competition depends on the ratio of the time scales of turbulent mixing and vertical flotation. We note that the Péclet number is species specific, because the vertical velocity is different for different species. The model simulations indicate that the buoyant cyanobacterium Microcystis wins the competition when it is able to overtop the sinking green algae and diatoms, and therefore, we focus here on the Péclet number from the perspective of Microcystis. If the vertical flotation velocity of Microcystis exceeds the rate of turbulent mixing (i.e. Pe $\gg 1$ ), Microcystis will float upwards and forms a bloom in the upper metres of the water column, and hence outcompetes the diatoms and green algae. Conversely, if the vertical flotation velocity does not dominate over turbulent mixing (i.e. $P e \ll 1$ ), Microcystis cannot form a surface bloom but remains homogeneously mixed, and the diatoms and green algae win (Fig. 2).

In deeper waters, the boundary line between dominance of either the buoyant cyanobacterium Microcystis or the sinking diatoms and green algae bends off and becomes independent of the depth of the water column (Fig. 2). In these deep waters, a phytoplankter has sufficient time to produce several daughter cells before it is transported across the depth of the water column by mixing or flotation. In this case, the vertical positions of the buoyant versus sinking species depend not only on the time scales of mixing, flotation and sinking, but on the time scale of phytoplankton growth as well. More specifically, the asymptotic expansion rate of a growing phytoplankton population would be given by the square root of $4 \mu_{i}\left(I_{\text {in }}\right) D$ (e.g. Riley et al. 1949; Skellam 1951), where we evaluated the near-surface growth rate at an incident light intensity $I_{\text {in }}$. Hence, the upward movement of a buoyant phytoplankton population is given by the sum of its upward expansion by population growth and its upward flux by flotation. Likewise, the upward movement of a sinking phytoplankton population is given by the sum of its upward expansion by population growth minus its downward flux by sinking. The winner of competition for light is the species that gets on top and therefore put its competitors in its shade. Therefore, we introduce a new dimensionless number that compares the upward movement of the buoyant versus sinking species, to indicate which species will get on top. We have called this dimensionless number the competition number $C$ :

$C=\frac{\sqrt{4 \mu_{s}\left(I_{\text {in }}\right) D}-v_{s}}{\sqrt{4 \mu_{b}\left(I_{\text {in }}\right) D}+v_{b}}$

where we use the subscript $b$ for the buoyant cyanobacteria and the subscript $s$ for the sinking diatoms and green algae. If $C \ll 1$, the population of buoyant cyanobacteria moves upwards faster and wins the competition. If $C \gg 1$, the population expansion of the diatoms and green algae is sufficiently large to overcome their own sinking losses and the upward movement of the competing buoyant cyanobacteria, and hence, the diatoms and green algae win (Fig. 2).

These dimensionless numbers can be applied to estimate, roughly, the level of turbulence that is required to switch a system from dominance by buoyant cyanobacteria to dominance by sinking diatoms and green algae. For instance, Lake Nieuwe Meer in The Netherlands has an average watercolumn depth of $z_{M}=18 \mathrm{~m}$, and therefore, we focus on the Péclet number. Let us assume that the Microcystis population in Lake Nieuwe Meer has an average flotation velocity of $v_{i}=0.5 \mathrm{~m} \mathrm{~h}^{-1}$. Microcystis will float upwards and forms a surface bloom if $P e \gg 1$, let's say $P e>10$. Rearranging Eq. (3), this will occur if the turbulent diffusivity remains below $D<v_{i} z_{M} / 10$. Accordingly, Microcystis is predicted to develop surface blooms if $D<0.9 \mathrm{~m}^{2} \mathrm{~h}^{-1}$ or equivalently $D<2.5 \mathrm{~cm}^{2} \mathrm{~s}^{-1}$. The turbulence generated by artificial mixing of the real lake exceeded this critical value, and hence, indeed artificial mixing of the lake prevented surface blooms of Microcystis and shifted the species composition towards diatoms and green algae (Huisman et al. 2004). 
The above theory is of course still a major simplification of the full complexity of the real world. However, the population dynamics outlined in Eq. (1) can be incorporated in more complex numerical models that also cover other aspects of relevance for cyanobacterial growth, such as changes in nutrient availability and temporal and spatial variability in hydrodynamical flows. For instance, growth of $\mathrm{An}$ abaena circinalis in the Myponga Reservoir, an artificially destratified reservoir in South Australia, was modelled with the phytoplankton community model PROTECH (Lewis et al. 2002) and with the coupled hydrodynamic-ecological numerical model DYRESM-CAEDYM (Lewis et al. 2004). In addition to artificial mixing, also chemical dosing with $\mathrm{CuSO}_{4}$ was used to manage cyanobacterial growth in this reservoir. Both models successfully predicted the dynamics of the dominant phytoplankton species in the reservoir when different management strategies were applied. In another study, the DYRESMCAEDYM model was used to explore the effects of several different artificial destratification designs on Microcystis biomass in a eutrophic reservoir in Argentina (Antenucci et al. 2003). The model predicted that the best results would be obtained by the combination of a deep diffuser to suppress phosphorus release from the sediments by oxygenation of the hypolimnion and a shallow diffuser to enhance vertical mixing in the surface layer. Hence, these numerical models can be very useful to assist effective management of cyanobacterial blooms in lakes and reservoirs.

\section{Buoyancy regulation}

In the preceding theory section, we assumed that the vertical flotation velocities of cyanobacteria were constant, which is a common assumption in several model studies (e.g. Bormans and Condie 1998; Huisman et al. 2004; Jöhnk et al. 2008). However, many cyanobacteria possess buoyancy regulation mechanisms, which allow them to actively control their vertical position in the water column. Examples include Anabaena (Oliver and Walsby 1988), Microcystis (Kromkamp and Mur 1984; Ibelings et al. 1991; Visser et al. 1996b), Aphanizomenon (Konopka 1989) and Oscillatoria (Walsby et al. 1983). Extensive reviews of the factors affecting buoyancy regulation are given by Reynolds (1987), Oliver (1994) and
Walsby (1994). There are three possible mechanisms of buoyancy regulation: (1) changes in the rates of synthesis of gas vesicles, (2) changes in cell ballast (mainly carbohydrate and protein content) and (3) gas vesicle collapse by rising turgor pressure. However, this latter mechanism is probably not responsible for buoyancy regulation in natural populations (Walsby 1994), because many species (including Microcystis spp.) have gas vesicles too strong to be collapsed by combined turgor and hydrostatic pressures (Kromkamp et al. 1986). According to the carbohydrate ballast mechanism, the concentration of carbohydrates in the cells depends on the temporal integration of carbon storage during the day by photosynthesis and by reductions in carbon storage during the night by respiration. This mechanism has been demonstrated in Oscillatoria (Utkilen et al. 1985), Microcystis (Kromkamp and Mur 1984; Thomas and Walsby 1985), Aphanizomenon (Konopka et al. 1987) and Anabaena (Kinsman et al. 1991). Gas vesicles synthesis is stimulated by low irradiance and allows cyanobacteria a faster return towards illuminated surface layers when water column stability permits this (Deacon and Walsby 1990). In contrast, a period of low irradiance caused by deep mixing in Lake Windermere induced over buoyancy of the Anabaena colonies, where the cells produced so many gas vesicles that the normal buoyancy regulating mechanisms no longer operated (Walsby et al. 1991). This enhanced the risk of surface bloom formation, where the high irradiance and temperature in the scum, combined with total depletion of carbon greatly increased the risk of photodamage (Ibelings 1996; Ibelings and Maberly 1998).

Both light and nutrients are important factors in the regulation of buoyancy in cyanobacteria. A large number of papers describe how cyanobacteria genera change their buoyancy in response to light changes in laboratory experiments (Thomas and Walsby 1985; Kromkamp et al. 1988) or through the diel cycle of light and dark in field experiments (Ibelings et al. 1991; Wallace and Hamilton 1999). All studies consistently report an increase in buoyancy under low light and a decrease under high light. Based on laboratory experiments of changes in carbohydrate content of cells at different irradiances, Visser et al. (1997) suggested empirical relationships for the rate of density changes of Microcystis as a function of light. These particular relationships have subsequently been used in many applications (e.g. Chien et al. 2013). Far 
fewer studies have concentrated on the nutrient response, and they report a consistent decrease in buoyancy under $\mathrm{N}$ and $\mathrm{P}$ limitation and a buoyancy increase under $\mathrm{N}$ and $\mathrm{P}$ replenishment (Klemer et al. 1996; Brookes and Ganf 2001; Chu et al. 2007). In natural conditions, Bormans et al. (1999) combined field observations from several Australian systems with studies reported in the literature to show that no field studies reported evidence for population migration to sufficient depth to reach nutrients in stratified systems. Instead, changes in vertical distribution of phytoplankton were either a response to light or a response to the dynamics of the mixed layer.

\section{Modelling vertical migration and mixing in lakes}

Models of increasing complexity have been progressively developed to study vertical migration of cyanobacteria. Changes in flotation velocity due to changes in the density of cyanobacterial cells were incorporated into Stokes' equation in the work of Kromkamp and Walsby (1990) and Visser et al. (1997). The latter two studies built upon laboratory experiments, which showed that cyanobacteria change their density in response to the diurnal light cycle, as they accumulate carbohydrate ballast during the daytime and respire these carbohydrates during the night. Gas vesicles to cell volume ratios and cell volume to colony volume ratios were added by Rabouille and Salençon (2005) and Aparicio Medrano et al. (2013), while non-uniform colony size distribution was included by Chien et al. (2013). However, no models to date include explicitly the buoyancy response to gradients in nutrients.

Vertical migration is affected by turbulent mixing, which modifies the depth distribution and the light dose received. Hence, a combination of a buoyancy regulation model and a hydrodynamic model is required to explain dynamic changes in the vertical distribution of cyanobacteria under natural conditions. Several authors have developed such coupled hydrodynamical and buoyancy regulation models and successfully applied them to natural conditions (Bormans and Condie 1998; Howard 1997; Wallace and Hamilton 2000; Aparicio Medrano et al. 2013). As cyanobacterial species differ in their morphology, they also have different vertical migration velocities, ranging from a few $\mathrm{cm} \mathrm{d}^{-1}$ for small unicellular cyanobacteria to several $\mathrm{m} \mathrm{d}^{-1}$ for large colonies of Microcystis. Consequently, the intensity of mixing required to entrain the cyanobacteria into the turbulent flow is highly dependent on the species. Large Microcystis colonies will require a much higher mixing rate to remain uniformly entrained than small unicells or filaments.

\section{Mixing devices}

Aeration systems

Systems bringing air under higher pressure can break the stratification and induce mixing of the water column. In this way, bottom water is moved upwards. The depth of the air inlet is important: the greater the depth, the more efficient the mixing is (Cooke et al. 1993). Lorenzen and Fast (1977) concluded that an air flow rate of $9.2 \mathrm{~m}^{3} \mathrm{~min}^{-1} \mathrm{~km}^{-2}$ lake area should be sufficient to accomplish adequate surface reaeration and other benefits of circulation in most lakes. However, it is uncertain whether this flow rate is also sufficient to keep cyanobacterial colonies entrained. For the efficiency, it is also important to consider whether the aeration is from one point or from several outlets in a pipe. With several outlets, one can produce curtains of bubbles, which cover a larger area than one single bubble plume. Most studies listed in Table 1 made use of aerators with a compressor pumping compressed air through a diffuser or pipe with holes in it. In Lake Dalbang (South Korea), aerators were used of the intermittent bubble blaster type (Heo and Kim 2004). Here, air is compressed inside a cylinder until it is released at once to produce a large bubble that pushes water upwards, bringing hypolimnetic water up to the surface.

\section{Mechanical destratification devices}

Pumping warm water downwards (down flow systems) or cold water upwards reduces the temperature differences across the thermocline and thus potentially induces mixing of the water column. Two types of pumps have been developed for the destratification of lakes: (1) axial flow pumps with a large propeller that generates a low velocity jet and (2) a direct drive mixer with a small propeller that generates high velocity jets (Cooke et al. 1993). However, this form of mechanical 


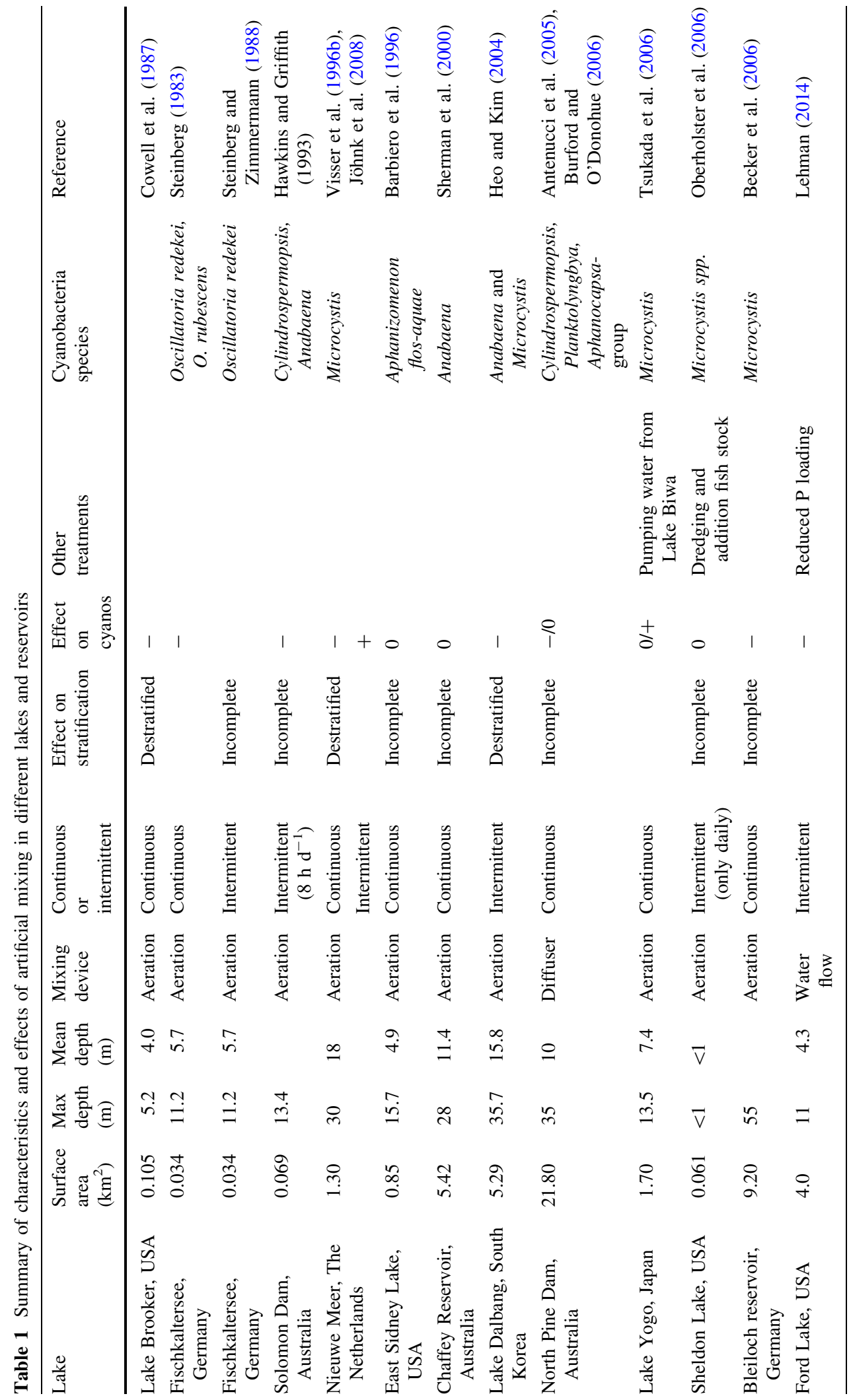


mixing is less efficient than aeration (Symons et al. 1967, 1970; Knoppert et al. 1970) and has been used less frequently (Cooke et al. 1993).

\section{Solar-powered water mixers}

These devices are up-flow water circulators that pump water to the surface through an intake hose and transport it radially in all directions to improve surface flows (Upadhyay et al. 2013). Generally, only the epilimnetic water is circulated and stratification is maintained. These mixers have thus a limited zone of influence and are unable to adequately mix entire lakes to effectively control cyanobacteria (Upadhyay et al. 2013). In contrast, Hudnell et al. (2010) showed that solar-powered circulation suppressed cyanobacterial densities in two reservoirs. Here, several so-called Solar Bees $\subset$ were installed in reservoirs, and intake hoses were set at depths at the base of the photic zone, usually just above the thermocline. It is surprising that cyanobacteria were suppressed without mixing to a depth below the epilimnion.

\section{Effects of artificial mixing}

We confined this literature review to those studies that applied artificial mixing with the aim to control cyanobacteria in lakes (see Table 1 for the studied lakes and their characteristics). This implies that also studies were included in which the result of mixing was only partial destratification. Not all changes in variables were reported in detail in the studies and in order to give an overview of general changes observed in artificially mixed lakes, we also refer to some other studies in the evaluation of physical, chemical and biological changes below. We did not include studies where a combination of different measures made it impossible to decipher the contribution of artificial mixing to lake restoration.

\section{Temperature}

The primary effect of artificial mixing is to increase the mixed layer depth. As a result of artificial mixing, the temperature of the total (mixed) water body generally decreases if one compares it to the temperature of the epilimnion in the lake when it was stratified (Cooke et al. 1993). In Lake Dalbang, South
Korea, the maximum surface temperature decreased from 28.9 to $26.4{ }^{\circ} \mathrm{C}$ after destratification, whereas the maximum hypolimnetic temperature increased from 8.0 to $23.7^{\circ} \mathrm{C}$ (Heo and Kim 2004). In Lake Nieuwe Meer, The Netherlands, the maximum surface temperature decreased from 23.4 to $19.1{ }^{\circ} \mathrm{C}$ after aeration, whereas the maximum temperature in the deeper layers increased from 8.0 to $19.1{ }^{\circ} \mathrm{C}$ (Visser et al. 1996b). In shallower lakes, changes in temperature are less obvious or not observed at all (e.g. Cowell et al. 1987).

An increase in temperature of the hypolimnion will affect biogeochemical processes at the sediment-water interface. For instance, higher temperatures may cause an increased mineralization of organic material accumulated in the sediment, which may result in a higher phosphorus $(\mathrm{P})$ release from the sediment into the water column depending on the oxygen conditions.

\section{Oxygen}

By artificial circulation, high oxygen concentrations in the top layers obtained from atmospheric exchange and primary production are transported to depth. Furthermore, oxygen is also brought into the water column if the artificial mixing is generated by aeration with compressed air. Hence, the principal, and probably the most reliable, effect of artificial mixing is to raise the total dissolved oxygen concentration throughout the lake, and particularly in the bottom waters (Cooke et al. 1993). Indeed, this result can be found in many studies that measured and reported the oxygen content of the lake (Cowell et al. 1987; Cooke et al. 1993; Visser et al. 1996b; Heo and Kim 2004; Lehman 2014).

Higher oxygen concentrations in the hypolimnion enlarge suitable habitat for a large number of oxygendependent organisms such as zooplankton and fish (Doke et al. 1995; Klumb et al. 2004; Skinner et al. 2014) and avoid fish kills by preventing the upwelling of anoxic hypolimnetic water (Müller and Stadelmann 2004). Enhanced oxygen availability also has major effects on many biogeochemical processes. For instance, the creation of aerobic conditions in the hypolimnion may decrease $\mathrm{P}$ release from the sediments (see below) and may improve water quality by suppressing the accumulation of high concentrations of ammonium and sulphide (Beutel 2006). 
Acidity

In many studies, the $\mathrm{pH}$ in the top layer was lowered with $0.5-1$ units as a result of mixing of carbon dioxide-rich hypolimnion water with carbon dioxidepoor epilimnion water or as a result of decreased primary production through deeper mixing (Cowell et al. 1987; Cooke et al. 1993; Visser et al. 1996b).

\section{Nutrients}

In terms of total $\mathrm{P}$, opposite results have been found depending on the type of system and sediment characteristics. In some studies, a decrease in total $\mathrm{P}$ indicates a decreased internal loading due to more oxidized conditions near the sediment. Sherman et al. (2000), for instance, showed that the amount of soluble reactive phosphorus released from the sediments in the Chaffey Reservoir, in Australia, decreased by about $80 \%$ due to enhanced oxygen transport to the hypolimnion by artificial destratification. In other studies, total $\mathrm{P}$ increased, possibly due to mixing of nutrient-rich water from the hypolimnion into the upper layers (Osgood and Stiegler 1990) or to enhanced mineralization of P-containing organic matter. The study of Gächter and Wehrli (1998) based on 10 years of experience with artificial mixing and hypolimnetic oxygenation in two eutrophic lakes concluded that these techniques could not prevent anoxic conditions below the water-sediment interface due to high sedimentation rates of organic matter, and consequently, the techniques did not affect the internal cycling of $\mathrm{P}$ in the lakes. Accordingly, the effects of artificial mixing on internal $\mathrm{P}$ loading vary across lakes, and in several eutrophic lakes mixing appeared to have only a minor effect on the internal $\mathrm{P}$ loading. More details on the effects of hypolimnetic oxygenation on internal $\mathrm{P}$ loading are presented elsewhere in this issue (Bormans et al. 2015).

\section{Transparency}

The light extinction coefficient did not change considerably in many continuously mixed lakes. In the intermittently mixed Lake Fischkaltersee, however, the transparency as measured with a Secchi disc did increase and was regularly more than $2 \mathrm{~m}$ (Steinberg and Zimmermann 1988). The same lake did not show this enhanced transparency when continuously mixed.

\section{Phytoplankton biomass}

In general, chlorophyll concentrations hardly changed as a result of mixing (e.g. Heo and Kim 2004), although both increases (Steinberg 1983) and decreases (Cowell et al. 1987; Steinberg and Zimmermann 1988; Visser et al. 1996b) were observed as well. Complete circulation may cause changes in the total algal biomass integrated over the entire depth of the water column, i.e. in $\mathrm{mg}$ chlorophyll per $\mathrm{m}^{2}$. Whether this standing crop will increase or decrease during complete mixing depends on the limitation factor of the phytoplankton. Models simulating the total biomass per unit surface area as a function of mixing depth (Lorenzen and Mitchell 1973; Oskam 1978; Huisman and Weissing 1995; Diehl 2002) show that with increasing mixing depth the biomass initially will increase, until a mixing depth where nutrient limitation is replaced by light limitation, causing a decrease in biomass with further increases in mixing depth (Fig. 3). The biomass per surface area of lightlimited phytoplankton decreases with increasing mixing depth, because more light is absorbed by water, and hence, less is available for growth of the plankton (Huisman et al. 1999; Diehl et al. 2002).

Indeed, in most cases an increase in total chlorophyll per $\mathrm{m}^{2}$ was found when a water system was

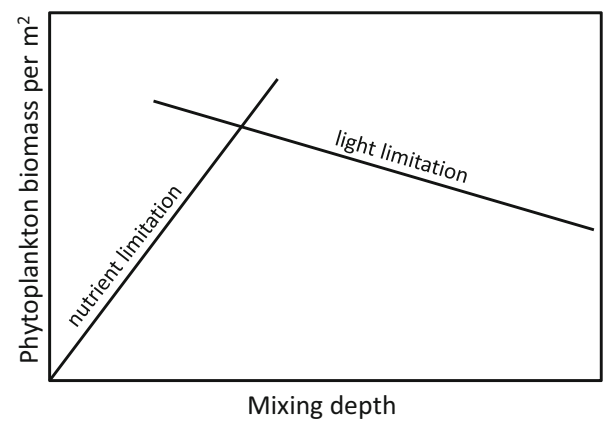

Fig. 3 Generalized plot of total phytoplankton biomass per unit surface area as function of mixing depth for both nutrient- and light-limited phytoplankton. With an increase in mixing depth initially the larger availability of nutrients alleviates nutrient limitation and stimulates biomass, however, at a given mixing depth light limitation takes over from nutrients as limiting resource and biomass goes down (modified after Lorenzen and Mitchell 1973) 
mixed (Pastorok et al. 1980; Toetz 1981; Steinberg 1983; Hawkins and Griffiths 1993; Visser et al. 1996b; Heo and Kim 2004). This can be explained by nutrient limitation of the phytoplankton: more nutrients become available for growth per unit surface area, and moreover, the concentration of nutrients in the hypolimnion is often higher than in the epilimnion, so that when the two are combined through destratification the availability of nutrients in the euphotic zone increases. Also decreased sedimentation losses of the phytoplankton are suggested as an explanation for increased biomass per surface area (Toetz 1981; Visser et al. 1996b; Diehl et al. 2002). In order to establish a decrease in total algal biomass, the mixing depth should be further increased. Although a lower total algal biomass has not been reached in many studies, this does not imply that artificial mixing was unsuccessful. In many cases, dense surface blooms disappeared and the phytoplankton species composition shifted away from cyanobacteria, in line with the desired result.

\section{Phytoplankton composition}

A shift from cyanobacteria to green algae and/or diatoms is often found in artificially mixed lakes (Table 1; Haynes 1973; Toetz 1977; Cowell et al. 1987; Steinberg and Zimmermann 1988; Hawkins and Griffiths 1993; Visser et al. 1996b; Heo and Kim 2004; Huisman et al. 2004; Becker et al. 2006; Lehman 2014). A decrease in cyanobacterial dominance can be understood when the conditions resulting from artificial mixing of a lake are compared with the physical requirements for cyanobacterial dominance. Decreasing stability, temperature and $\mathrm{pH}$ in a mixed lake are generally not favourable for cyanobacteria (Cooke et al. 1993; Paerl and Huisman 2009). In Lake Nieuwe Meer (Visser et al. 1996b; Huisman et al. 2004), decreased sedimentation losses in the mixed lake were implicated as being responsible for the increased number of green algae and diatoms. The sedimentation loss rate of the green alga Scenedesmus in the stratified and mixed lake was described in relation to the mixing depth by Visser et al. (1996a). This loss rate was almost equal to the measured intrinsic sinking velocity divided by the mixing depth, in line with theoretical predictions (Smith 1982; Diehl 2002). Higher silica availability might also have contributed to enhanced growth of diatoms.
Reduction in growth of Microcystis was found by Toetz (1981), Visser et al. (1996b) and Lilndenschmidt (1999) in an artificially mixed lake. Elimination of Planktothrix agardhii during continuous mixing was found in Lake Fischkaltersee (Steinberg 1983). Its reappearance after complete absence for 2 years (Steinberg 1983; Steinberg and Tille-Backhaus 1990) showed that this species is turbulence tolerant. Also, Reynolds et al. (1983) observed favourable conditions for Planktothrix if the ratio of $Z_{\mathrm{m}} / Z_{\text {eu }}$ is higher than 2 . However, its abundance could be set back by intermittent mixing in Lake Fishkaltersee (Steinberg and Zimmermann, 1988). In the study of Heo and Kim (2004), the $Z_{\mathrm{m}} / Z_{\text {eu }}$ in the mixed Lake Dalbang was $2.5 \mathrm{~m}$ and the mixing succeeded to eliminate Anabaena. $Z_{\mathrm{m}} / Z_{\mathrm{eu}}>1$ causes phytoplankton to be mixed below the euphotic depth and the higher this ratio becomes, the longer the phytoplankton remains in the dark.

A successful decline of cyanobacteria has been found in a reservoir that was not completely mixed (Becker et al. 2006), but in this particular case the euphotic zone was very shallow due to strong background attenuation, thus leading to a very high $Z_{\mathrm{m}} / Z_{\mathrm{eu}}$ ratio.

The mixing rate can also affect the outcome of competition. Forsberg and Shapiro (1980) studied the response of phytoplankton to mixing depth and rates in enclosures and concluded that cyanobacteria increased in relative abundance at the slower mixing rates while green algae and diatoms were favoured by the fastest mixing intensities. The shift to green algae occurred only during conditions of low $\mathrm{pH}$ and rapid mixing in this study. It should be noted that the maximum depth of the enclosures was only $8 \mathrm{~m}$.

Cyanobacterial abundance is not always decreased by artificial mixing (e.g. Knoppert et al. 1970; Lackey 1973; Osgood and Stiegler 1990; Barbiero et al. 1996; Oberholster et al. 2006; Tsukada et al. 2006). Pastorok et al. (1980) summarized the results of a large number of destratification case studies: of 24 lake experiments, the number of cyanobacteria decreased in 12 cases, increased in 8 cases and no change was observed in 4 cases. McAuliffe and Rosich (1990, in Sherman et al. 2000) reported that there was no improvement in the amount or type of algae in more than $70 \%$ of reservoirs with artificial destratification in Australia. In Lake Yogo (Japan), Tsukada et al. (2006) observed that destratification through aeration was not strong 
enough to prevent cyanobacterial blooms. Lackey (1973) reported an increase in the cyanobacteria Anabaena flos-aquae, Aphanizomenon flos-aquae and Gomphosphaeria lacustris in the artificially mixed Parvin Lake (USA). In the artificially destratified North Pine Dam, Australia, abundance of Cylindrospermopsis was not affected by the mixing but correlations of this dominant cyanobacterium with other genera indicated that prior to destratification its competitive advantage involved its ability to compete for $\mathrm{P}$, whereas after destratification it involved its ability to compete for light. Furthermore, mixing will not have the desired effect if a lake is too shallow, e.g. in an urban lake in Colorada, USA, with a depth of less than a metre, artificial mixing did not affect the cyanobacterial dominance (Oberholster et al. 2006).

The mixing efficiency generally weakens further away from the device. For example, in Bleiloch Reservoir (Becker et al. 2006), the temperature difference between the epilimnion and hypolimnion increased at increasing distances to the diffuser. At the site close to the diffuser, the cyanobacterial abundance had decreased, but cyanobacteria were more abundant at larger distance of the diffuser. In a comparison between an artificially mixed reservoir (North Pine reservoir) and two naturally mixed reservoirs (Wivenhoe and Somerset Reservoirs), significant differences in the phytoplankton composition were only observed for the site close to the dam wall where the diffusers were located (Burford and O'Donohue 2006). This indicates that the mixing was effective close to the aerator but ineffective at greater distance. Taken all sites together, still a difference could be found in lower peaks of cyanobacterial abundance in North Pine Reservoir with a destratification unit compared to the other reservoirs. Minor effects of mixing included differences in the successional patterns in abundance of the dominant genera. However, the artificially mixed North Pine Reservoir did not show major differences in algal species composition compared to the other two non-mixed reservoirs. An earlier study on this reservoir (Antenucci et al. 2005) in which 11 years before and 7 years after installation of the destratification device was compared concluded: 'A strong spatial gradient in phytoplankton abundance and chlorophyll a was observed, with low abundance in the downstream regions affected by the destratification system which was likely because of light limitation induced by vertical mixing. The upstream region acted as a surrogate for the unaltered state of the reservoir, particularly as an indicator of eutrophication without direct influence from the destratification system'.

\section{Zooplankton}

Only a few studies investigated effects of artificial mixing on zooplankton, but Becker et al. (2006) showed that destratification caused an increase in the zooplankton abundances. Effects on higher trophic levels were not investigated in the papers we studied, but from other papers it is known that mixing may also benefit fish abundance (e.g. Vašek et al. 2013).

\section{Determination of mixing efficiency}

Hydrodynamic models testing the effect of artificial mixing on cyanobacterial growth have been sparse. Microcystis distribution and growth before and during artificial mixing have been modelled by Huisman et al. (2004), with changes in vertical diffusivity calculated from detailed profiles of the temperature microstructure measured with a Self-Contained Autonomous MicroProfiler (SCAMP). They showed that the interplay between mixing and access to light determined the changes in phytoplankton composition controlling Microcystis growth. Jöhnk et al. (2008) developed a model explaining the failure of intermittent artificial mixing to control a Microcystis bloom. The coupling between a hydrodynamic model, driven by meteorological data during an extreme summer heat wave, and a phytoplankton growth model, with functions for temperature, light and buoyancy regulation, provided further insight into the environmental conditions promoting cyanobacterial blooms. These papers showed that the level of the turbulent diffusivity is of great importance to determine whether or not mixing will be successful.

Entrainment of cyanobacterial colonies in the turbulent flow can be determined by assessment of buoyancy changes (i.e. carbohydrate accumulation or breakdown). The carbohydrate content of a cell is a direct result of its photosynthetic activity. Hence, it can serve to give an indication of the light history of the cells (Ibelings et al. 1991). A linear relation between the carbohydrate accumulation and growth rate was found by Foy (1983). Direct measurements of 
the growth rate in the field are difficult, but carbohydrates or buoyancy state can be easily measured. Buoyancy of colonies at deep and shallow mixed locations in the artificially mixed Lake Nieuwe Meer (Visser et al. 1996b) showed that Microcystis produced less carbohydrate when entrainment by the artificially induced turbulence was efficient and mixing was deep. From these determinations, it could be concluded that on sunny, calm days, colonies could escape the mixing at some locations in the lake that were apparently less well mixed than locations closer to the bubble plumes. At these less-well-mixed locations, an accumulation of colonies in the surface layer occurred.

Chlorophyll fluorescence can also provide information on the light history of algal cells, which can be used to obtain insight into the degree of mixing of the water column and the entrainment of cyanobacteria in the turbulent flow (Harris 1980; Huot and Babin 2010). Upadhyay et al. (2013) determined the variable fluorescence ratio $\mathrm{Fv} / \mathrm{Fm}$, which is a good quantitative indicator of the quantum yield of photosystem II, before and after turning on the mixing device and observed a more depressed $\mathrm{Fv} / \mathrm{Fm}$ at the surface compared to deeper in the water column before turning the device on. When the mixing was on, the difference over depth was much smaller, although the effect weakened at increasing distances.

\section{Preconditions for a successful application}

Artificial mixing in lakes was not successful if the system was (1) not sufficiently well mixed vertically, (2) too shallow or (3) if the horizontal distribution of mixing devices was inadequate to cover the entire lake. If the mixing rate is not high enough to entrain the cyanobacteria and decrease their light exposure, colony-forming cyanobacteria can easily 'escape' from the turbulent flow due to their high flotation velocity.

Artificial mixing will only be effective in rather deep lakes. Distinction has to be made between colonies and filaments: colony-forming species, such as Microcystis, have a much higher flotation velocity and the mixing velocity of the water needs to be high enough to keep the colonies entrained in the turbulent flow. Filamentous cyanobacteria, such as Planktothrix, have a much lower flotation velocity, which greatly reduces the required mixing rate. In The Netherlands, Planktothrix-dominated lakes are mostly shallow ( $<4 \mathrm{~m}$, Schreurs 1992) and typically polymictic, such that the Planktothrix filaments are already entrained by natural mixing. It can be expected that artificial mixing will not reduce the Planktothrix biomass in these lakes.

The minimum depth of the lakes in which artificial mixing was successful to reduce Microcystis was $15.8 \mathrm{~m}$ (Table 1, Heo and Kim 2004), but lakes where other cyanobacterial species were successfully controlled were shallower. What the minimum depth is for successful suppression of cyanobacteria by artificial mixing is still unknown and depends on several environmental factors. An important factor is light attenuation in the water column, because a substantial reduction in light availability for phytoplankton photosynthesis can be established at a shallower mixing depth in a turbid lake than in a clear lake. Therefore, the ratio of mixing depth to euphotic depth is usually more informative than the mixing depth itself. For example, Sherman et al. (2000) found that the ratio of the surface mixed layer to the euphotic depth should be larger than 3 to impose light limitation and reduce the abundance of Anabaena circinalis. A similar ratio of $Z_{\mathrm{m}} / Z_{\mathrm{eu}}>3$ was observed to limit the growth of Cylindrospermopsis raciborskii (Bormans et al. 2005).

Results of Steinberg and Zimmermann (1988) as well as calculations by Oskam (1978) and Jungo et al. (2001) suggest that in most lakes continuous mixing down to a depth of less than $15 \mathrm{~m}$ would not induce sufficient light limitation to successfully control cyanobacteria such as Microcystis. According to Lilndenschmidt (1999), continuous artificial mixing in shallow lakes $(<15 \mathrm{~m})$ enhances cyanobacterial growth since light limitation is not likely to occur already at these depths and mixing just above the sediment may bring more $\mathrm{P}$ into the water column. Here, intermittent mixing as tested in Fischkaltersee (Steinberg and Zimmermann 1988) or surge aeration as in Lake Tegel (Lilndenschmidt 1999) might be a solution to reduce cyanobacterial abundance.

\section{Mixing regimes}

Intermittent mixing (to reduce energy costs) would be possible to prevent growth of non-colonial cyanobacteria, 
but colonial cyanobacteria may benefit from the periods of stability by their high flotation rate. Colonial cyanobacteria are able to quickly return to the upper layer and benefit from the higher photon irradiance in periods without mixing. In fact, this is the natural behaviour for colony-forming cyanobacteria such as Microcystis. They are well adapted to conditions of varying mixing intensity, rapidly floating up into the illuminated surface mixed layer during — even briefperiods of quiescence (sometimes described as 'tracking the surface mixed layer', Humphries and Lyne 1988). Smaller colonies or filaments need several hours or days to rise from deep layers to the euphotic zone and will receive only a small light dose when mixing intermittently takes them to greater depth. Moreover, the small colonies or filaments present in the upper layer are not able to escape the high irradiance, even when they manage to build up enough carbohydrate to loose buoyancy, since their sinking rates are too low [as was shown in a simulation of vertical migration of Microcystis colonies of various sizes (Visser et al. 1997)]. Especially when cyanobacteria were previously deeply mixed and thus adapted to low irradiance, they are vulnerable to photoinhibition and potentially photooxidation. Köhler (1992) showed a delay in the growth of Microcystis when the mixing depth suddenly decreased.

During the growing season of Microcystis, from about mid-July till mid-September, continuous mixing would be the best regime to prevent growth. Intermittent mixing might cause a Microcystis bloom because of the occurrence of temporal stratification that Microcystis can use to concentrate in the upper layers. Especially during hot summers, intermittent mixing will not be sufficient to reduce the growth of Microcystis. For example, an intermittent mixing regime in which artificial mixing was alternately switched on and off for periods of 14 days was tested in one of the hottest summers ever recorded in Europe (2003) and resulted in a bloom of Microcystis (Jöhnk et al. 2008).

However, in spring an intermittent mixing regime can be applied in order to reduce energy costs. In this time of the year, Microcystis has not yet build up a large population and the mixing has been applied with the aim to prevent anoxic conditions. In Lake Nieuwe Meer, this was successfully tested in 1994. Stratification and oxygen depletion were prevented by mixing during 1 or 2 days after a couple of days without mixing. The biomass of negatively buoyant algae was somewhat lower in this period, which was probably due to increased sedimentation losses compared to continuous mixing.

\section{Cost-effectiveness}

Recent information on costs for installation and operation is scarce in the literature. Dierberg and Williams (1989) provide some information on costs in several projects in Florida: the initial installation costs ranged between $\$ 2.780$ and $\$ 3.280$ per $\mathrm{km}^{2}$. Annual operational costs ranged from $\$ 8.300$ to $\$ 157.800$ per $\mathrm{km}^{2}$. These costs were evaluated as modest relative to other restoration techniques. The costs of installation of a new aeration system in Lake Nieuwe Meer were estimated to amount to $€ 750.000$ per $\mathrm{km}^{2}$ while the operational and energy costs are about $€ 25.000$ per year (internal report, STOWA 2010 (38), The Netherlands). The costs in The Netherlands are higher because the water managers aim at a higher mixing velocity to assure mitigation of cyanobacterial blooms, while in Florida the aeration systems could be less powerful since these were mainly used to prevent summer fish kills.

Even the higher costs for the installation in The Netherlands easily outweigh the revenue losses that may be caused by cyanobacterial blooms occurring in a lake or reservoir. In Australia, the revenue loss after an Anabaena bloom in the Darling River was estimated at 10 million Australian dollar (Mitrovic et al. 2011). In the USA, the estimated loss on recreational revenue due to cyanobacterial blooms was estimated at $0.37-1.16$ billion dollar per year (Dodds et al. 2009).

\section{Conclusions and recommendations}

From the overview of various studies in which artificial mixing was applied to control cyanobacteria, we can conclude that artificial mixing can be an effective measure to establish a shift in the phytoplankton composition from cyanobacteria to green algae and diatoms. Reducing the external nutrient input in the lake or reservoir, however, should still be the main focus in restoration studies to improve the water quality on the long term. However, in the short term and in lakes with an open connection to eutrophic rivers, artificial mixing could be a good solution to 
prevent nuisance blooms of cyanobacteria. It has been used in several lakes to improve the water quality. Preconditions for successful applications are as follows: (1) mixing rate should be sufficiently high to entrain the cyanobacteria in the turbulent flow, (2) the mixing should be deep enough to sufficiently limit light availability and (3) the distribution of aerators or mechanical mixers should be designed in a way that a sufficiently large part of the lake participates in the artificially induced turbulent flow (given the bathymetry of the lake). However, the number of successful studies is limited, and there is a substantial variation in the devices used for mixing and how they are positioned (or distributed) in water systems. Response variables measured in the mixed lake or reservoir also varied substantially. This variation impedes the exact description of restrictions that are needed to make the measure successful. Hence, for each system a tailormade solution should be developed.

The bathymetry of a lake or reservoir can also influence the effectiveness of artificial mixing. In deep, bath tub-like water systems it will work best. In lakes with a complex bathymetry, it will be less effective, since precondition 3 gets more easily violated. Studies in shallow lakes have shown that artificial mixing often does not reduce the cyanobacterial abundance, because here precondition 2 is not easily fulfilled. From lake studies, models, and physiological investigations, the mechanism for the shift from cyanobacteria to green algae and diatoms is well understood in an artificially mixed system. Cyanobacteria lose their advantage of buoyancy to float up into the upper illuminated layers if they are entrained in the turbulent flow. On the other hand, negatively buoyant phytoplankton such as green algae and diatoms profits from the mixed conditions since their sedimentation losses decline with increasing mixing depth. Due to a higher growth rate of the eukaryotic phytoplankton, cyanobacteria will lose the competition and greens and diatoms will dominate. Moreover, investigation of the photophysiology of Microcystis versus the green alga Scenedesmus showed that the photosynthetic machinery of the cyanobacterium deals less well with fluctuating irradiance than the green alga.

Future research could focus on the growth response of these organisms to differences in light dose and fluctuations (i.e. a relationship between growth rate and $Z_{\mathrm{m}} / Z_{\mathrm{eu}}$ ratios should be established). Combined with known sedimentation losses of negatively buoyant algae, this would give more precise information regarding the mixing depth required for a shift in phytoplankton away from cyanobacteria.

An additional advantage of this controlling measure is that, in potential, artificial mixing may also have positive ecological effects on other organisms despite a high eutrophication state of the lake or reservoir. Indeed, only air is added to the water and water quality is improved since blooms of potentially toxic cyanobacteria are replaced by edible eukaryotic green algae and diatoms while also the oxygen content in the lake is increased. Artificial mixing can reduce internal $\mathrm{P}$ loading from the sediment by hypolimnetic oxygenation and contribute in this way to a more sustainable restoration when it goes hand in hand with cleaning up sources of external nutrient loading.

However, a clear drawback is that mixing should be continued during the entire growing season and that the installation, operation and energy costs of artificial mixing are relatively high. The high-energy usage and the need to continue mixing of the lake as long as nutrients have not been sufficiently reduced to solve the problems result in a low score in sustainability of the measure. An intermittent mixing regime might help to reduce the energy costs and could be useful against non-colonial cyanobacteria with a relatively low flotation velocity. Yet, continuous mixing will be more effective to suppress summer blooms of colonial cyanobacteria, such as Microcystis, which can quickly profit from the established stratification during unmixed periods.

Open Access This article is distributed under the terms of the Creative Commons Attribution 4.0 International License (http:// creativecommons.org/licenses/by/4.0/), which permits unrestricted use, distribution, and reproduction in any medium, provided you give appropriate credit to the original author(s) and the source, provide a link to the Creative Commons license, and indicate if changes were made.

\section{References}

Antenucci JP, Alexander R, Romero JR, Imberger J (2003) Management strategies for a eutrophic water supply reservoir: San Roque, Argentina. Water Sci Technol 47:149-155

Antenucci JP, Ghadouani A, Burford MA, Romero JR (2005) The long-term effect of artificial destratification on phytoplankton species composition in a subtropical reservoir. Freshw Biol 50:1081-1093 
Aparicio Medrano E, Uittenbogaard RE, Dionisio Pires LM, van de Wiel BJH, Clercx HJH (2013) Coupling hydrodynamics and buoyancy regulation in Microcystis aeruginosa for its vertical distribution in lakes. Ecol Model 248:41-56

Ashley KI (1983) Hypolimnetic aeration of a naturally eutrophic lake: physical and chemical effects. Can Fish Aquat Sci 40:1343-1359

Barbiero RP, Speziale BJ, Ashby SL (1996) Phytoplankton community succession in a lake subjected to artificial circulation. Hydrobiologia 331:109-120

Becker A, Herschel A, Wilhelm C (2006) Biological effects of incomplete destratification of hypertrophic freshwater reservoir. Hydrobiologia 559:85-100

Beutel MW (2006) Inhibition of ammonia release from anoxic profundal sediments in lakes using hypolimnetic oxygenation. Ecol Eng 28:271-279

Bormans M, Condie SA (1998) Modelling the distribution of Anabaena and Melosira in a stratified river weir pool. Hydrobiologia 364:3-13

Bormans M, Sherman BS, Webster IT (1999) Is buoyancy regulation in cyanobacteria an adaptation to exploit separation of light and nutrients? Mar Freshw Res 50:897-906

Bormans M, Ford P, Fabbro L (2005) Spatial and temporal variability in cyanobacterial populations controlled by physical processes. J Plankton Res 27:61-70

Bormans M, Jancula D, Marsalek B (2015) Controlling internal phosphorus loading in lakes by physical methods to reduce cyanobacterial blooms: a review. Aquat Ecol (This issue)

Brookes JD, Ganf GG (2001) Variations in the buoyancy response of Microcystis aeruginosa to nitrogen, phosphorus and light. J Plankton Res 23:1399-1411

Burford MA, O'Donohue MJ (2006) A comparison of phytoplankton community assemblages in artificially and naturally mixed subtropical water reservoirs. Freshw Biol 51:973-982

Carey CC, Ibelings BW, Hoffmann EP, Hamilton DP, Brookes JD (2012) Eco-physiological adaptations that favour freshwater cyanobacteria in a changing climate. Wat Res 46:1394-1407

Chien YC, Wu SC, Chen WC, Chou CC (2013) Model simulation of diurnal vertical migration patterns of differentsized colonies of Microcystis employing a particle trajectory approach. Environ Eng Sci 30:179-186

Chu Z, Jin X, Yang B, Zeng Q (2007) Buoyancy regulation of Microcystis flos-aquae during phosphorus-limited and nitrogen-limited growth. J Plankton Res 29:739-745

Condie SA (1999) Settling regimes for non-motile particles in stratified waters. Deep-Sea Res I 46:681-699

Cooke GD, Welch EB, Peterson SA, Newroth PR (1993) Artificial circulation. In: Cooke GD, Welch EB, Peterson SA, Newroth PR (eds) Restoration and management of lakes and reservoirs. Lewis Publishers, London, pp 419-449

Cowell BC, Dawes CJ, Gardiner WE, Scheda SM (1987) The influence of whole lake aeration on the limnology of a hypereutrophic lake in central Florida. Hydrobiologia 148:3-24

Cox PA, Banack SA, Murch SJ (2003) Biomagnification of cyanobacterial neurotoxins and neurodegenerative disease among the Chamorro people of Guam. Proc Natl Acad Sci USA 100:13380-13383
Deacon C, Walsby AE (1990) Gas vesicle formation in the dark, and in light of different irradiances, by the cyanobacterium Microcystis sp. Brit Phycol J 25:133-139

Diehl S (2002) Phytoplankton, light, and nutrients in a gradient of mixing depths: theory. Ecology 83:386-398

Diehl S, Berger S, Ptacnik R, Wild A (2002) Phytoplankton, light, and nutrients in a gradient of mixing depths: field experiments. Ecology 83:399-411

Dierberg FE, Williams VP (1989) Lake management techniques in Florida, USA: costs and water quality effects. Environm Manage 13:729-742

Dodds W, Bouska W, Eitzmann J, Pilger T, Pitts K, Riley A, Schloesser J, Thornbrugh D (2009) Eutrophication of U.S. freshwaters: analysis of potential economic damages. Environ Sci Technol 43:12-19

Doke JL, Funk WH, Juul ST, Moore BC (1995) Habitat availability and benthic invertebrate population changes following alum treatment and hypolimnetic oxygenation in Newman Lake, Washington. J Freshw Ecol 10:87-102

Flameling IA, Kromkamp J (1997) Photoacclimation of Scenedesmus protuberans (Chlorophyceae) to fluctuating irradiances simulating vertical mixing. J Plankton Res 19:1011-1024

Forsberg BR, Shapiro J (1980) Predicting the algal response to destratification. In: Restoration of lakes and Inland waters. EPA 440/5-81-010. U.S. Envir Prot Ag, Washington, DC, pp 134-145

Foy RH (1983) Interaction of temperature and light on the growth rates of two planktonic Oscillatoria species under a short photoperiod regime. Br Phycol J 18:267-273

Gächter R, Wehrli B (1998) Ten years of artificial mixing and oxygenation: no effect on the internal phosphorus loading of two eutrophic lakes. Environ Sci Technol 32:3659-3665

Griffiths DJ, Saker ML (2003) The Palm Island mystery disease 20 years on: a review of research on the cyanotoxin cylindrospermopsin. Environ Toxicol 18:78-93

Harris GP (1980) The relationship between chlorophyll a fluorescence, diffuse attenuation changes and photosynthesis in natural phytoplankton populations. J Plankton Res 2:109-127

Hawkins PR, Griffiths DJ (1993) Artificial destratification of a small tropical reservoir: effects upon the phytoplankton. Hydrobiologia 254:169-181

Haynes RC (1973) Some ecological effects of artificial circulation on a small eutrophic lake with particular emphasis on phytoplankton. Hydrobiologia 43:463-504

Heo WM, Kim B (2004) The effect of artificial destratification on phytoplankton in a reservoir. Hydrobiologia 524:229-239

Hilborn ED, Carmichael WW, Soares RM, Yuan M, Servaites JC, Barton HA et al (2007) Serologic evaluation of human microcystin exposure. Environ Toxicol 22:459-463

Hooper FF, Ball RC, Tanner HA (1953) An experiment in the artificial circulation of a small Michigan lake. Trans Am Fish Soc 82:222-241

Howard A (1997) Computer simulation modelling of buoyancy change in Microcystis. Hydrobiologia 349:111-117

Hudnell HK, Jones C, Labisi B, Lucero V, Hill DR, Eilers J (2010) Freshwater harmful algal bloom (FHAB) suppression with solar powered circulation (SPC). Harmful Algae 9:208-217 
Huisman J, Sommeijer B (2002) Population dynamics of sinking phytoplankton in light-limited environments: simulation techniques and critical parameters. J Sea Res 48:83-96

Huisman J, Weissing FJ (1995) Competition for nutrients and light in a mixed water column: a theoretical analysis. Am Nat 146:536-564

Huisman J, Jonker RR, Zonneveld C, Weissing FJ (1999) Competition for light between phytoplankton species: experimental tests of mechanistic theory. Ecology 80:211-222

Huisman J, Sharples J, Stroom JM, Visser PM, Kardinaal WEA, Verspagen JMH, Sommeijer B (2004) Changes in turbulent mixing shift competition for light between phytoplankton species. Ecology 85:2960-2970

Humphries SE, Lyne VD (1988) Cyanophyte blooms: the role of cell buoyancy. Limnol Oceanogr 33:79-91

Huot Y, Babin M (2010) Overview of fluorescence protocols: theory, basic concepts, and practice. In: Chlorophyll a fluorescence in aquatic sciences: methods and applications. Springer, The Netherlands, pp 31-74

Ibelings BW (1996) Changes in photosynthesis in response to combined irradiance and temperature stress in cyanobacterial surface waterblooms. J Phycol 32:549-557

Ibelings BW, Maberly SC (1998) Photoinhibition and the availability of inorganic carbon restrict photosynthesis by surface blooms of cyanobacteria. Limnol Oceanogr 43:408-419

Ibelings BW, Mur LR, Kinsman R, Walsby AE (1991) Microcystis aeruginosa changes its buoyancy in response to the average irradiance in the surface mixed layer. Arch Hydrobiol 120:385-401

Ibelings BW, Kroon B, Mur LR (1994) Acclimation of photosystem II in a cyanobacterium and a eukaryotic green alga to high and fluctuating photosynthetic photon flux densities, simulating light regimes induced by mixing in lakes. New Phytol 128:407-424

Ibelings BW, Backer LC, Kardinaal WEA, Chorus I (2014) Current approaches to cyanotoxin risk assessment and risk management around the globe. Harmful Algae 40:63-74

Jäger CG, Diehl S, Schmidt GM (2008) Influence of watercolumn depth and mixing on phytoplankton biomass, community composition, and nutrients. Limnol Oceanogr 53:2361

Jähnichen S, Jäschke K, Wieland F, Packroff G, Benndorf J (2011) Spatio-temporal distribution of cell-bound and dissolved geosmin in Wahnbach reservoir: causes and potential odour nuisances in raw water. Wat Res 45:4973-4982

Jöhnk KD, Huisman J, Sharples J, Sommeijer B, Visser PM, Stroom JM (2008) Summer heatwaves promote blooms of harmful cyanobacteria. Global Change Biol 14:495-512

Jungo E, Visser PM, Stroom J, Mur LR (2001) Artificial mixing to reduce growth of the blue-green alga Microcystis in Lake Nieuwe Meer, Amsterdam: the design of the aeration system and an overview of 6 years experience. Wat Sci Technol Water Supply 1:17-23

Kinsman R, Ibelings BW, Walsby AE (1991) Gas vesicle collapse by turgor pressure and its role in buoyancy regulation by Anabaena flos-aquae. J Gen Microbiol 137:1171-1178

Klausmeier CA, Litchman E (2001) Algal games: the vertical distribution of phytoplankton in poorly mixed water columns. Limnol Oceanogr 46:1998-2007
Klemer AR, Cullen JJ, Mageau MT, Hanson KM, Sundell RA (1996) Cyanobacterial buoyancy regulation: the paradoxical roles of carbon. J Phycol 32:47-53

Klumb RA, Bunch KL, Mills EL, Rudstam LG, Brown G, Knauf C, Burton R, Arrhenius F (2004) Establishment of a metalimnetic oxygen refuge for zooplankton in a productive Lake Ontario embayment. Ecol Appl 14:113-131

Knoppert PL, Rook JJ, Hofker T, Oskam G (1970) Destratification experiments in Rotterdam. J Am Water Works Ass 62:448-454

Köhler J (1992) Influence of turbulent mixing on growth and primary production of Microcystis aeruginosa in the hypertrophic Bautzen Reservoir. Arch Hydrobiol 123:413-429

Konopka A (1989) Metalimnetic cyanobacteria in hard-water lakes: Buoyancy regulation and physiological state. Limnol Oceanogr 34:1174-1184

Konopka A, Kromkamp J, Mur LR (1987) Regulation of gas vesicle content and buoyancy in light-or phosphate-limited cultures of Aphanizomenon flos-aquae (cyanophyta) 1. J Phycol 23:70-78

Kromkamp JC, Mur LR (1984) Buoyant density changes in the cyanobacterium Microcystis aeruginosa due to changes in the cellular carbohydrate content. FEMS Microbiol Lett 25:105-109

Kromkamp J, Walsby AE (1990) A computer model of buoyancy and vertical migration in cyanobacteria. J Plankton Res 12:161-183

Kromkamp J, Konopka A, Mur LR (1986) Buoyancy regulation in a strain of Aphanizomenon flos-aquae (Cyanophyceae): the importance of carbohydrate accumulation and gas vesicle collapse. J Gen Microbiol 132:2113-2121

Kromkamp J, Konopka A, Mur LR (1988) Buoyancy regulation in light-limited continuous cultures of Microcystis aeruginosa. J Plankton Res 10:171-183

Kuiper-Goodman T, Falconer I, Fitzgerald J (1999) Human health aspects. In: Chorus I, Bartram J (eds) Toxic cyanobacteria in water: a guide to their public health consequences, monitoring and management. London, UK, E \& FN Spon, pp 113-153

Lackey RT (1973) Artificial reservoir destratification effects on phytoplankton. J WPCF 45:668-673

Lehman JT (2011) Nuisance cyanobacteria in an urbanized impoundment: interacting internal phosphorus loading, nitrogen metabolism, and polymixis. Hydrobiologia 661:277-287

Lehman JT (2014) Understanding the role of induced mixing for management of nuisance algal blooms in an urbanized reservoir. Lake Reserv Manage 30:63-71

Lewis DM, Elliott JA, Lambert MF, Reynolds CS (2002) The simulation of an Australian reservoir using a phytoplankton community model: PROTECH. Ecol Model 150:107-116

Lewis DM, Brookes JD, Lambert MF (2004) Numerical models for management of Anabaena circinalis. J Appl Phycol 16:457-468

Lilndenschmidt KE (1999) Controlling the growth of Microcystis using surged artificial aeration. Internat Rev Hydrobiol 84:243-254

Litchman E (2000) Growth rates of phytoplankton under fluctuating light. Freshw Biol 44:223-235

Lorenzen MW, Fast R (1977) A guide to aeration/circulation techniques for lake management. Res Ser EPA-600/3-77004, U.S. Environ Prot Agency 
Lorenzen M, Mitchell R (1973) Theoretical effects of artificial destratification on algal production in impoundments. Environ Sci Technol 7:939-944

Mantzouki E, Visser PM, Bormans M, Ibelings BW (2015) Understanding the key ecological traits of cyanobacteria as a basis for their management and control under expected environmental changes. Aquat Ecol. doi:10.1007/s10452015-9526-3

McAuliffe TF, Rosich RS (1990) Review of artificial destratification of water storages in Australia. Research report no. 9, Urban Water Research Association of Australia, Melbourne

Merel S, Walker D, Chicana R, Snyder S, Baurès E, Thomas O (2013) State of knowledge and concerns on cyanobacterial blooms and cyanotoxins. Environ Int 59:303-327

Mitrovic SM, Howden CG, Bowling LC, Buckney RT (2003) Unusual allometry between in situ growth of freshwater phytoplankton under static and fluctuating light environments: possible implications for dominance. J Plankton Res 25:517-526

Mitrovic SM, Hardwick L, Dorani F (2011) Use of flow management to mitigate cyanobacterial blooms in the Lower Darling River, Australia. J Plankton Res 33:229-241

Müller R, Stadelmann P (2004) Fish habitat requirements as the basis for rehabilitation of eutrophic lakes by oxygenation. Fish Manage Ecol 11:251-260

Nicklisch A (1998) Growth and light absorption of some planktonic cyanobacteria, diatoms and Chlorophyceae under simulated natural light fluctuations. J Plankton Res 20:105-119

Oberholster PJ, Botha AM, Cloete TE (2006) Toxic cyanobacterial blooms in a shallow, artificially mixed urban lake in Colorado, USA. Lakes Reserv Res Manage 11:111-123

O'Brien KR, Ivey GN, Hamilton DP, Waite AM, Visser PM (2003) Simple mixing criteria for the growth of negatively buoyant phytoplankton. Limnol Oceanogr 48:1326-1337

Oliver RL (1994) Floating and sinking in gas-vacuolate cyanobacteria. J Phycol 30:161-173

Oliver RL, Walsby AE (1988) Buoyancy and suspension of planktonic cyanobacteria. Methods Enzymol 16:521-552

Osgood RA, Stiegler JE (1990) The effects of artificial circulation on a hypereutrophic lake. Water Res Bull 26:209-217

Oskam G (1978) Light and zooplankton as algae regulating factors in eutrophic Biesbosch reservoirs. Verh Int Verein Limnol 20:1612-1618

Paerl HW, Huisman J (2009) Climate change: a catalyst for global expansion of harmful cyanobacterial blooms. Environ Microbiol Rep 1:27-37

Pastorok RA, Ginn TC, Lorenzen MW (1980) Review of aeration/circulation for lake management. In: Restoration of lakes and inland waters. EPA 440/5-81-010. U.S. Envir Prot Ag, Washington DC, pp 124-133

Ptacnik R, Diehl S, Berger S (2003) Performance of sinking and nonsinking phytoplankton taxa in a gradient of mixing depths. Limnol Oceanogr 48:1903-1912

Rabouille SAM, Salençon MJ (2005) Functional analysis of Microcystis vertical migration: a dynamic model as a prospecting tool. II. Influence of mixing, thermal stratification and colony diameter on biomass production. Aquat Microb Ecol 39:281-292
Reynolds CS (1987) Cyanobacterial water-blooms. Adv Bot Res 13:67-143

Reynolds CS, Wiseman SW, Godfrey BM, Butterwick C (1983) Some effects of artificial mixing on the dynamics of phytoplankton populations in large limnetic enclosures. J Plankton Res 5:203-234

Riley GA, Stommel H, Bumpus DF (1949) Quantitative ecology of the plankton of the western North Atlantic. Bull Bingham Oceanograph Coll 12:1-169

Schreurs H (1992) Cyanobacterial dominance: relations to eutrophication and lake morphology. Thesis, University of Amsterdam, 198 pp

Shapiro J (1979) The need for more biology in lake restoration. Lake Restoration Report

Sherman B, Whittington J, Oliver R (2000) The impact of artificial destratification on water quality in Chaffey Reservoir. Arch Hydrobiol Spec Issue Advanc Limnol 55:15-29

Skellam JG (1951) Random dispersal in theoretical populations. Biometrika 38:196-218

Skinner MM, Moore BC, Swanson ME (2014) Hypolimnetic oxygenation in Twin Lakes, WA. Part II: feeding ecology of a mixed cold- and warmwater fish community. Lake Reserv Manage 30:240-249

Smith IR (1982) A simple theory of algal deposition. Freshw Biol 12:445-449

Sommer U (1988) Growth and survival strategies of planktonic diatoms. In: Sandgren CD (ed) Growth and reproductive strategies of freshwater phytoplankton. Cambridge University Press, Cambridge, pp 227-260

Steinberg C (1983) Effects of artificial destratification on the phytoplankton populations in a small lake. J Plankton Res 5:855-864

Steinberg C, Tille-Backhaus R (1990) Re-occurrence of filamentous planktonic cyanobacteria during permanent artificial destratification. J Plankton Res 12:661-664

Steinberg C, Zimmermann GM (1988) Intermittent destratification: a therapy measure against cyanobacteria in lakes. Environ Technol Lett 9:337-350

Symons JM, Irwin WH, Robinson EL, Robeck GG (1967) Impoundment destratification for raw water quality control using either mechanical or diffused-air-pumping. J Am Water Works Ass 59:1268-1291

Symons JM, Carswell JK, Robeck GG (1970) Mixing of water supply reservoirs for quality control. J Am Water Works Ass 62:322-334

Taggart CT, McQueen DJ (1981) Hypolimnetic aeration of a small eutrophic kettle lake: physical and chemical changes. Arch Hydrobiol 91:150-180

Thomas RH, Walsby AE (1985) Buoyancy regulation in a strain of Microcystis. J Gen Microbiol 131:799-809

Toetz DW (1977) Effects of whole lake mixing with an axial flow pump on water chemistry and phytoplankton. Hydrobiologia 55:129-138

Toetz DW (1981) Effects of whole lake mixing on water quality and phytoplankton. Water Res 15:1205-1210

Tsukada H, Tsujimura S, Nakahara H (2006) Seasonal succession of phytoplankton in Lake Yogo over 2 years: effect of artificial manipulation. Limnology 7:3-14

Upadhyay S, Bierlein KA, Little JC, Burch MD, Elam KP, Brookes JD (2013) Mixing potential of a surface-mounted 
solar-powered water mixer (SWM) for controlling cyanobacterial blooms. Ecol Eng 61:245-250

Utkilen HC, Oliver RL, Walsby AE (1985) Buoyancy regulation in a red Oscillatoria unable to collapse gas vacuoles by turgor pressure. Arch Hydrobiol 102:319-329

Vašek M, Prchalová M, Peterka J, Ketelaars HA, Wagenvoort AJ, Čech M, Draštíka V, Milan R, Juzaa T, Kratochvíla M, Mrkvickaad T, Blabolil P, Boukale DS, Durasg J, Kubečka J (2013) The utility of predatory fish in biomanipulation of deep reservoirs. Ecol Eng 52:104-111

Visser PM, Ibelings BW, Van der Veer B, Koedood J, Mur LR (1996a) Artificial mixing prevents nuisance blooms of the cyanobacterium Microcystis in Lake Nieuwe Meer, the Netherlands. Freshw Biol 36:435-450

Visser PM, Massaut L, Huisman J, Mur LR (1996b) Sedimentation losses of Scenedesmus in relation to mixing depth. Arch Hydrobiol 136:289-308
Visser PM, Passarge J, Mur LR (1997) Modelling vertical migration of the cyanobacterium Microcystis. Hydrobiologia 349:99-109

Wallace BB, Hamilton DP (1999) The effect of variations in irradiance on buoyancy regulation in Microcystis aeruginosa. Limnol Oceanogr 44:273-281

Wallace BB, Hamilton DP (2000) Simulation of water-bloom formation in the cyanobacterium Microcystis aeruginosa. J Plankton Res 22:1127-1138

Walsby AE (1994) Gas vesicles. Microbiol Rev 58:94-144

Walsby AE, Utkilen HC, Johnsen IJ (1983) Buoyancy changes of a red coloured Oscillatoria agardhii in Lake Gjersjoeen, Norway. Arch Hydrobiol 97:18-38

Walsby AE, Kinsman R, Ibelings BW, Reynolds CS (1991) Highly buoyant colonies of the cyanobacterium Anabaena lemmermannii form persistent surface waterblooms. Arch Hydrobiol 121:261-280 